STUDIA I MATERIAŁY

DOI: 10.18276/SIP.2017.47/3-37

\title{
Pavel Zhebrouski*
}

Szkoła Główna Handlowa w Warszawie, Kolegium Gospodarki Światowej

\section{ANALIZA REGULACJI BRANŻY HAZARDOWEJ NA PRZYKŁADZIE ZAKŁADÓW WZAJEMNYCH W WYBRANYCH KRAJACH UE: ZNACZENIE DLA GOSPODARKI}

\begin{abstract}
Streszczenie
Wraz z globalnym rozwojem technologicznym rynek hazardu staje się powszechnie akceptowalną formą rozrywki i nabiera coraz większego znaczenia ekonomicznego dla gospodarek poszczególnych państw. W niniejszym artykule podjęto tematykę związaną z regulacjami rynku zakładów wzajemnych, będącego częścią szeroko pojmowanego rynku hazardu, w wybranych krajach Unii Europejskiej. W artykule dokonano analizy porównawczej regulacji prawno-podatkowych w zakresie rynku zakładów wzajemnych, która wskazuje, iż dominującym podejściem w państwach członkowskich UE jest model kontrolowanej liberalizacji, który w większym stopniu niż alternatywny model restrykcyjny sprzyja dynamicznemu rozwojowi danego rynku, a tym samym większym korzyściom dla gospodarek poszczególnych krajów, m.in. w postaci zwiększonych wpływów budżetowych.
\end{abstract}

Słowa kluczowe: hazard, zakłady wzajemne, operatorzy offshore, podatek od GGR (Gross Gaming Revenue), Ustawa hazardowa

\footnotetext{
* Adres e-mail: p.e.zebrowski@gmail.com.
} 


\section{Wprowadzenie}

Hazard jest złożonym zjawiskiem, analiza którego wymaga spojrzenia wielopłaszczyznowego. Historycznie zjawisko hazardu znane jest ludzkości od dawnych czasów: wiadomo, iż jeszcze w starożytnym Rzymie przyjmowano zakłady na pojedynki gladiatorów, przy tym nierzadko Rzymianie przegrywali całe majątki, niewolników czy też własne żony (Pieszin, Pieskow, 2016, s. 151). Już wtedy gry hazardowe wiązały się również z nieuczciwymi praktykami: w czasie prac archeologicznych w grobowcu jednego z faraonów odnaleziono nietypową kość przeznaczoną do gry, która miała przesunięty środek ciężkości. Nie dziwi więc fakt, iż już w dawnych czasach rozumiano zagrożenia moralne, które płyną z uprawiania hazardu, dlatego też w Rzymie, Sparcie, Bizancjum czy Rusi Kijowskiej podejmowano działania, które miały na celu ograniczenie bądź całkowity zakaz takiej działalności (Pieszin i in., s. 152).

Oficjalne zakazy nie przyczyniły się jednak do wykorzenienia danego zjawiska ani w czasach starożytnych, ani w późniejszym okresie średniowiecza. W różnych postaciach hazard towarzyszył kolejnym pokoleniom, mimo iż najważniejsze religie zabraniały uczestnictwa w grach hazardowych, m.in. Koran całkowicie potępia hazard, a gry hazardowe są w krajach muzułmańskich albo całkowicie zakazane, albo znacząco ograniczone. Chrześcijaństwo również nie patrzy na hazard przychylnym okiem (Binde, 2007, s. 153-157). Z biegiem czasu natomiast paradygmat o bezwzględnej szkodliwości uprawiania gier hazardowych przyczynił się do tego, iż dawne zakazy religijne zastąpiły zaostrzenia prawne (Barwaśny, 2014, s. 140).

Na przełomie XX i XXI wieku, wraz z nasileniem się procesów globalizacyjnych, zmianami uwarunkowań ekonomicznych oraz dynamicznym rozwojem technologicznym, hazard zaczął być postrzegany jako jedna z form rekreacji. Rosnący popyt na usługi hazardowe jest uwarunkowany wpływem następujących czynników:

- laicyzacją społeczeństwa oraz liberalizacją poglądów moralnych i etycznych na uprawianie hazardu;

- wzrostem dochodów społeczeństwa, a tym samym większej ilości środków przeznaczanych na aktywności rozrywkowe i rekreacyjne;

- gotowością władz lokalnych do legalizacji świadczenia usług w zakresie hazardu w celu osiągnięcia korzyści ekonomicznych dla gospodarki; 
- integracją oferowanych usług hazardowych z innymi popularnymi formami rozrywki (profesjonalne wydarzenia sportowe, wyścigi samochodowe, wyścigi konne);

- wzrostem interaktywnych usług hazardowych oferowanych na podstawie technologii telekomunikacyjnych, jak również szerokim spektrum nowych kanałów świadczenia usług w zakresie hazardu (Izryadnova, 2016).

Ogół powyższych czynników prowadzi do tego, że sektor hazardowy zyskuje obecnie coraz większe znaczenie ekonomiczne, a co za tym idzie, staje się przedmiotem regulacji prawnych. Regulacje te różnią się w krajach UE w zależności od przyjętego przez lokalnego ustawodawcę modelu regulacji poszczególnych rodzajów hazardu oraz celów, które zamierza on tym samym osiągnąć.

W obliczu problematyki związanej z różnorodnym podejściem ustawodawców w państwach członkowskich UE do powyższego zagadnienia, celem niniejszego artykułu jest dokonanie krytycznej analizy porównawczej regulacji prawno-podatkowych dotyczących rynku zakładów wzajemnych oraz zweryfikowanie skuteczności modeli przyjętych przez ustawodawców w państwach członkowskich UE przez pryzmat kosztów i korzyści dla gospodarek poszczególnych krajów.

\section{Charakterystyka rynku zakładów wzajemnych}

Obecnie trzy najważniejsze rodzaje hazardu to loterie, gry hazardowe (np. ruletka, poker, blackjack czy automaty) oraz zakłady wzajemne. Przedmiotem analizy w danym artykule jest ten ostatni rodzaj hazardu. Zakłady wzajemne mogą być definiowane jako obstawianie środków pieniężnych na wyniki poszczególnych zdarzeń sportowych (np. piłka nożna, hokej na lodzie czy skoki narciarskie) oraz społeczno-politycznych (np. zwycięzca konkursu Eurowizja czy następny premier Wielkiej Brytanii). Ze względu na miejsce i formę zawierania zakładów rynek zakładów wzajemnych dzieli się na sferę offline (zakłady są zawierane w fizycznie istniejących specjalnych punktach) oraz sferę online, która umożliwia świadczenie usług $\mathrm{w}$ internecie za pomocą stron internetowych oraz aplikacji mobilnych, po uprzedniej weryfikacji użytkownika.

Warto podkreślić, iż obecnie rozwój rynku hazardowego w skali globalnej jest determinowany przez transformację technologiczną, która prowadzi do ekspansji kanału internetowego. W szczególności w 2016 roku sfera zakładów wzajemnych 
online wykazała wzrost dochodów o 11,8\% wobec 3,6\% wzrostu sfery offline w skalie globalnej (Rub90, 2017). Wiąże się to z faktem, iż rośnie liczba użytkowników korzystających z usług hazardowych za pomocą internetu oraz urządzeń mobilnych. Warto tu zaznaczyć, iż w 2015 roku udział sektora online wyniósł 17\% w łącznej wielkości europejskiego rynku hazardu, z kolei według prognoz udział ten wzrośnie do poziomu 22\% i wielkości 24,9 mld euro w roku 2020 (European Gambling \& Betting Association, Market Reality, 2016). Z kolei udział rynku zakładów wzajemnych online w ogólnej wielkości rynku hazardu online wynosi $37 \%$, posiadając tym samym największy udział spośród innych rodzajów hazardu online, jak poker (24\%) czy kasyno (22\%) (European Gambling \& Betting Association, Market Reality, 2016).

Wśród dostawców usług zakładów wzajemnych online wyróżnia się tzw. operatów onshore oraz offshore. Do pierwszej grupy zalicza się operatorów, którzy posiadają lokalną licencję i odprowadzają lokalne podatki i opłaty, natomiast operatorzy offshore świadczą usługi w zakresie zakładów wzajemnych na podstawie rejestracji i licencji wydanych w innych jurysdykcjach, na rzecz których odprowadzają podatki. W zależności od przyjętego przez dany kraj modelu regulacji lub potencjalnych zmian w jego ustawodawstwie, dostawcy usług w zakresie zakładów wzajemnych podejmują decyzję odnośnie do ubiegania się o lokalną licencję i, tym samym, przejścia do strefy onshore.

Wśród głównych celów w zakresie regulacji hazardu można wymienić: utworzenie dodatkowego źródła wpływów do budżetu państwa, zapobieganie takim zjawiskom kryminalnym jak oszustwa czy pranie brudnych pieniędzy oraz ochrona społeczeństwa przed niekorzystnymi skutkami hazardu. Biorąc pod uwagę wyżej wymienione cele, lokalny ustawodawca może zastosować szerokie spektrum rozwiązań odnośnie do branży hazardu, w tym również rynku zakładów wzajemnych. Podejście organów regulacyjnych ma bezpośrednie przełożenie na poziom udziału operatorów onshore w rynku zakładów wzajemnych w danym kraju. Ze względu na wysokość stawek podatkowych, rodzaje dopuszczalnych licencjowanych produktów (m.in. loterii i gier online) oraz rozwiązań w zakresie dozwolonej reklamy i promocji można wyodrębnić liberalne i restrykcyjne reżimy podatkowe.

Punktem wyjścia dla wprowadzenia liberalnych przepisów jest przekonanie, że zapewnienie lokalnie licencjowanym operatorom możliwości świadczenia atrakcyjnej oferty dla klientów, tj. potencjalnie wyższych wygranych, przełoży się w kon- 
sekwencji na większą popularność lokalnych uczestników rynku wśród użytkowników korzystających z usług zakładów wzajemnych. Liberalne przepisy umożliwiają operatorom świadczenie szerokiego spektrum usług hazardowych oraz prowadzenie kampanii marketingowych i sponsoringowych, co więcej, bardzo rzadko skutkują blokowaniem dostępu do stron internetowych operatorów offshore: wszystko to, co w konsekwencji prowadzi do większego udziału operatorów onshore w rynku zakładów wzajemnych, a co za tym idzie, likwidacji ,szarej strefy” oraz zwiększenia wpływów budżetowych z podatków od działalności hazardowej. Z kolei za regulacjami restrykcyjnymi przemawia przekonanie ustawodawcy, iż większa kontrola rynku hazardowego pozwoli zapobiegać potencjalnym kosztom społecznym wynikającym z ryzyka związanego z hazardem (uzależenienie, oszustwa, przestępczość). Podejście takie wiąże się z dominacją sfery offshore nad onshore, ze względu na mniej korzystne oferty kierowane do klientów przez lokalnie licencjonowanych operatorów. Restrykcyjne reżimy prawne zakładają również blokowanie dostępu do stron internetowych oraz form płatności elektronicznych na rzecz nielicencjonowanych operatorów.

Jednym z zasadniczych aspektów, który decyduje o zachowaniu oraz decyzjach operatorów i klientów oraz perspektywach rozwoju rynku w danym kraju, jest reżim podatkowy. Wpływa on bezpośrednio na cenę hazardu, która jest definiowana jako koszty transakcyjne ponoszone przez klientów, składające się z marży i kosztów operatorów świadczących usługi hazardowe, w tym również zakłady wzajemne, oraz wysokości opłat na rzecz państwa (Roland Berger, 2016, s. 11). Warto podkreślić, iż nie tylko wysokość podatku, ale też jego struktura wpływa na rozwój rynku i decyzje podejmowane przez jego uczestników. Wynika to z faktu, iż lokalny regulator może oddziaływać na poziom wpływów budżetowych, wykorzystując różne formy podatków w odniesieniu do przedmiotu opodatkowania oraz jego wielkości. Ustawodawcy państw członkowskich Unii Europejskiej stosują dwa zasadnicze podejścia w kwestii opodatkowania zakładów wzajemnych w formie: podatku od stawek oraz tzw. podatku od GGR (Gross Gaming Revenue), czyli podatku od przychodów z hazardu brutto, który jest definiowany jako suma stawek klientów minus suma zwrotów operatora. Pierwsza wspomniana forma podatku jest pobierana jako część stawki gracza, stąd też ciężar tej formy opodatkowania jest ponoszony właśnie przez gracza, gdyż ma bezpośredni wpływ na potencjalną sumę zwrotu z zakładu (Roland Berger, 2016, s. 11). Z kolei podatek od GGR jest ponoszony 
przez operatora i naliczany na podstawie jego realnych przychodów. Firma Roland Berger wskazuje, iż optymalny poziom takiej stawki podatkowej kształtuje się na poziomie $20 \%$ (Roland Berger, 2016).

\section{Analiza regulacji zakładów wzajemnych w wybranych krajach Unii Europejskiej}

Branża hazardowa generuje coraz większe przychody i, tym samym, nabiera coraz większego znaczenia ekonomicznego. Jednak mimo coraz większego zainteresowania tego typu aktywnością oraz istotnych implikacji ekonomicznych sektor hazardu nie jest do końca zharmonizowany na poziomie prawa unijnego. W 2012 roku Komisja Europejska podjęła jedynie wstępne kroki do wprowadzenia pewnych zharmonizowanych norm dla rynków hazardowych w państwach członkowskich UE w postaci przyjęcia komunikatu $W$ kierunku kompleksowych europejskich ram w zakresie hazardu internetowego.

Brak konkretnych ram regulacyjnych skutkuje różnymi podejściami ustawodawców państw członkowskich do regulacji sektora hazardu, w tym rynku zakładów wzajemnych. Warto zaznaczyć, iż dwa kraje członkowskie UE (Szwecja i Finlandia) ustanowiły monopolistyczne reżimy regulacyjne sfery hazardu, natomiast $\mathrm{w}$ zdecydowanej większości państw członkowskich UE funkcjonują systemy licencyjne, które umożliwiają świadczenie usług hazardowych zasadniczo nieograniczonej liczbie operatorów. Z kolei analizując formy opodatkowania rynku zakładów wzajemnych w UE, należy zaznaczyć, iż w 17 spośród pozostałych 26 krajów członkowskich UE, które nie wprowadziły monopolistycznych reżimów regulacyjnych rynku sfery hazardu, przyjęto formę opodatkowania w postaci podatku od GGR. W perspektywie zmian zachodzących w reżimach regulacyjnych w poszczególnych krajach członkowskich można zaobserować tendencję do zmian formy opodatkowania rynku zakładów wzajemnych, która polega na odejściu od podatku od obrotu na rzecz podatku od GGR w celu zwiększenia udziału segmentu onshore oraz optymizacji wpływów podatkowych (np. Włochy, Bułgaria, Czechy, Dania, Litwa).

Działania lokalnych regulatorów w odniesieniu do rynku zakładów wzajemnych można zasadniczo podzielić na dwa odmienne podejścia: kontrolowana liberalizacja rynku oraz restrykcyjna polityka. Warto dokonać porównania danych modeli regulacyjnych na przykładzie krajów stosujących dwa wspomniane podejścia: modelu 
duńskiego, jako przykładu kontrolowanej liberalizacji, oraz modelu francuskiego, jako przykładu restrykcyjnej polityki wobec rynku zakładów wzajemnych. Zasadnicza różnica między danymi modelami polega na formie opodatkowania działalności w zakresie zakładów wzajemnych: Francja stosuje podatek od obrotów (od stawek), wysokość którego wynosi 9,6\%, natomiast ustawodawca duński wprowadził podatek od GGR w wysokości $20 \%$. Jak już wspomniano, podatek od obrotu ponoszony jest przez użytkownika, natomiast podatek od GGR płaci operator, co de facto czyni tę pierwszą formę mniej atrakcyjną dla graczy. Zarówno model duński, jak i francuski przewidują podobne środki w zakresie odpowiedzialnego hazardu, tj. wdrażają regulaminy odpowiedzialnej gry oraz krajowy system samowykluczenia dla uzależnionych graczy. Inną podobną cechą obu modeli jest fakt, iż ustawodawcy przewidzieli blokowanie dostępu graczy do stron internetowych operatorów nieposiadających lokalnej licencji oraz blokowanie transakcji płatniczych na rzecz operatorów offshore. Niemniej zbieżne są wyłącznie przewidziane przez ustawodawców środki blokujące, natomiast odmienny jest stopień ich wykorzystania oraz skutki ich realizacji przez oba kraje. Według analizy firmy Roland Berger (2016), wprowadzenie przez Francję blokady ISP (Internet Service Provider) w 2010 roku przyczyniło się do wzrostu udziału operatorów onshore w rynku zakładów wzajemnych o $20 \%$ po trzech latach od wprowadzenia blokowania stron internetowych operatorów offshore. Regulacje modelu duńskiego również przewidują możliwość blokowania dostępu do stron nielicencjonowanych operatorów, jednakże zostały one wprowadzone jedynie w celu wsparcia nowych regulacji z roku 2012, które były atrakcyjne zarówno dla operatorów, jak i dla graczy. Skutkowało to coraz większym zainteresowaniem operatorów w uzyskaniu duńskiej licencji oraz w konsekwencji doprowadziło do wzrostu udziału operatorów onshore w rynku o $56 \%$ po trzech latach od wdrożenia nowych regulacji prawnych. Obecnie operatorzy onshore stanowią ok. 90\% rynku zakładów wzajemnych w Danii. Warto również podkreślić, iż wartość wskaźnika GGR z zakładów wzajemnych na osobę dorosłą w 2015 roku wyniosła 14,7 euro we Francji wobec 41,9 euro w Danii. Na podstawie powyższej analizy porównawczej można stwierdzić, iż blokowanie dostępu do stron internetowych operatorów offshore jest skuteczne jedynie w ograniczonym stopniu bez odpowiednich regulacji prawnych, które sprzyjałyby atrakcyjności rynku zarówno dla graczy, w postaci lepszych kursów oraz szerokiego wachlarza usług hazardowych, jak i dla operatorów, zainteresowanych otrzymaniem lokalnej licencji. 
Analizując rynek usług hazardowych w Polsce, w tym również rynek zakładów wzajemnych, warto zaznaczyć, iż funkcjonuje on na podstawie ustawy z dnia 19 listopada 2009 r. o grach hazardowych, której ostatnia nowelizacja weszła w życie 1 kwietnia 2017 roku. W zamiarze ustawodawcy nowelizacja ma przyczynić się do zwiększenia poziomu wpływów budżetowych, zapewnienia wysokiego poziomu ochrony graczy przed negatywnymi skutkami hazardu oraz zmniejszenia skali „szarej strefy”. Mimo tak zakreślonych celów nowelizacja wzbudza liczne kontrowersje wśród graczy i operatorów zakładów wzajemnych (Surebety, 2016), gdyż nie zmienia zasadniczo systemu opodatkowania zakładów wzajemnych, który jest naliczany w postaci podatku od obrotu w wysokości $12 \%$, co jest rozwiązaniem niekorzystnym dla graczy i sprzyja poszukiwaniu lepszych ofert wśród operatorów offshore. Nowelizacja ustawy wprowadziła jednak m.in. możliwość blokowania dostępu do stron internetowych i płatności elektronicznych operatorów nieposiadających polskiej licencji, co skutkowało tym, iż najważniejsi operatorzy rynku zakładów wzajemnych (m.in. Pinnacle, William Hill, Bet 365, Betfair) zrezygnowali ze świadczenia usług dla użytkowników zarejestrowanych w Polsce. Warto podkreślić, iż rynek zakładów wzajemnych w Polsce jest nadal słabo rozwinięty (wskaźnik GGR z zakładów wzajemnych na osobę dorosłą w 2015 roku wyniósł 2,5 euro) w porównaniu nie tylko do krajów o liberalnych reżimach regulacyjnych (np. Wielka Brytania - 40,3 euro), ale i o restrykcyjnych regulacjach (Francja - 14,7 euro). Analiza nowelizacji ustawy wskazuje, iż wprowadzone zmiany przyczynią się do wzrostu wskaźnika GGR do poziomu 4,0 euro oraz udziału operatorów onshore w rynku do 54\% w 2020 roku (Roland Berger, 2016), jednak wydaje się, iż nadal nie stwarza optymalnych warunków dla dynamicznego rozwoju rynku zakładów wzajemnych w Polsce.

\section{Korzyści i zagrożenia wynikające z funkcjonowania rynku zakładów wzajemnych dla gospodarki kraju}

Hazard, akceptowany w postaci formy rozrywki i rekreacji, jest postrzegany jako dobro inne od większości oferowanych obecnie w gospodarce. Wynika to $\mathrm{z}$ faktu, iż konsumpcja dobra, jakim jest hazard, może prowadzić do zaniku racjonalności w decyzjach konsumenta i uzależnienia. Mimo iż ryzyko uzależnienia od zakładów wzajemnych jest niższe w porównaniu do innych form hazardu (Węgrzecka-Giluń, 
2012, s. 3), może ono powodować nie tylko szkodliwe konsekwencje materialne i zdrowotne dla uzależnionego i jego rodziny, ale również może wywoływać negatywne skutki ponoszone przez gospodarkę w postaci tzw. kosztów społecznych. Pojęcie „kosztów społecznych” może być oparte na odwróconym w pewnym stopniu twierdzeniu Pareta, które wskazuje, że społeczeństwo zyskuje jako całość, gdy jeden z członków społeczeństwa zyskuje, ale żaden inny nie traci (Zasadzki, Zasadzki, 2010, s. 84).

Pojęcie „kosztów społecznych” jest różnorodnie definiowane. Wśród najczęściej wskazywanych kosztów społecznych wynikających z uzależnienia od hazardu, w tym również w postaci zakładów wzajemnych, można wyróżnić: przestępczość głównie w zakresie karno-skarbowym w związku z zaciągniętymi długami osób uzależnionych; leczenie uzależnionych od hazardu; zwiększoną liczba rozwodów i samobójstw, obniżoną produktywność pracowników ze względu na absencje bądź wypalenie emocjonalne i depresję.

Poza wspomnianymi zagrożeniami i kosztami społecznymi, związanymi z branżą hazardową, rynek zakładów wzajemnych, będąc częścią szeroko pojmowanego rynku hazardowego, generuje również szereg korzyści ekonomicznych dla gospodarki kraju oraz innych interesariuszy. Skala korzyści może różnić się w zależności od dojrzałości krajowego rynku zakładów wzajemnych oraz obowiązujących regulacji prawnych i fiskalnych. Wśród najważniejszych korzyści należy wymienić: dodatkowe przychody do skarbu państwa $\mathrm{z}$ opodatkowania zakładów wzajemnych (np. W Wielkiej Brytanii sektor hazardu i zakładów bukmacherskich pozytywnie wpływa na gospodarkę kraju, generując w 2016 roku 2,3 mld GBP do brytyjskiego PKB (Thorpe, 2016)) oraz opłat licencyjnych wnoszonych przez operatorów; niższe bezrobocie i nadwyżkę konsumenta; przychody marketingowe z kampanii promocyjnych w mediach oraz wsparcie w postaci sponsoringu poszczególnych dyscyplin, konkursów czy drużyn sportowych (np. w Polsce obecnie najwięksi licencjonowani operatorzy zakładów wzajemnych zawiązali umowy partnerskie z najlepszymi zespołami piłkarskimi, takimi jak STS - Lech Poznań, Fortuna - Legia Warszawa, Totolotek - Lechia Gdańsk). Według analizy firmy Nielsen Sport wydatki sfery hazardu z tytułu sponsoringu na koszulkach zespołów sześciu najpopularniejszych piłkarskich lig europejskich (Premier League, Bundesliga, Serie A, Primera Division, Ligue 1 i Eredivisie) w sezonie 2015/2016 wynosiły $42 \mathrm{mln}$ euro (The European Football Jersey Report 2015/2016, 2016). Natomiast European Gaming \& Betting As- 
sociation szacuje, iż w 2015 wydatki firm bukmacherskich z tytułu sponsoringu polskiego sportu wynosiły około $11 \mathrm{mln}$ zł. Warto zaznaczyć, iż w roku 2009, tj. przed wejściem w życie obecnej tzw. ustawy hazardowej, zaangażowanie sponsorskie firm bukmacherskich wynosiło około $40 \mathrm{mln}$ zł (European Gaming \& Betting Association, Sponsoring sportu - firmy bukmacherskie w Polsce i Europie, 2015, s. 6).

\section{Podsumowanie}

W niniejszym artykule dokonano analizy regulacji prawno-podatkowych branży zakładów wzajemnych w wybranych państwach Unii Europejskiej, jak również przedstawiono potencjalne koszty i korzyści wynikające $\mathrm{z}$ funkcjonowania rynku zakładów wzajemnych. Na podstawie dokonanej analizy można stwierdzić, iż prawo europejskie nie zawiera konkretnych regulacji sektorowych dla branży hazardowej, w tym zakładów wzajemnych, w związku z czym ustawodawcy w krajach członkowskich UE ustalają własne reżimy prawno-podatkowe, regulujące funkcjonowanie rynku zakładów wzajemnych. W większości państwa członkowskie UE adaptują modele polityki kontrolowanej liberalizacji lub restrykcyjnego podejścia wobec branży zakładów wzajemnych. Cele przyświecające lokalnym ustawodawcom oraz decyzje podjęte na ich podstawie mają bezpośredni wpływ na atrakcyjność danego rynku dla graczy i operatorów świadczących usługi na rynku zakładów wzajemnych. Przeprowadzona analiza pozwala dojść do wniosku, iż większość państw członkowskich UE stosuje podejście kontrolowanej liberalizacji, które charakteryzuje się rozwiązaniem fiskalnym w formie podatku od GGR oraz ograniczonym wykorzystaniem narzędzi blokujących dostęp do stron internetowych i płatności na rzecz nielicencjowanych operatorów. W odniesieniu do Polski można wnioskować, iż nowelizacja tzw. ustawy hazardowej, która weszła w życie 1 kwietnia 2017 r., ograniczy udział „szarej strefy” w rynku, jednak tworząc przy tym mało komfortowe warunki dla operatorów i użytkowników i nie wykorzystując w pełni potencjału danego rynku.

Podsumowując, warto podkreślić, iż przyjęcie modelu kontrolowanej liberalizacji skutkuje większym zainteresowaniem wobec uzyskania lokalnej licencji do świadczenia usług zakładów wzajemnych oraz, w konsekwencji, większymi wpływami do budżetu państwa oraz niwelowaniem udziału „szarej strefy” w wielkości lokalnego rynku zakładów wzajemnych. 


\section{Literatura}

Barwaśny, D. (2014). Zasady świadczenia usług w zakresie gier hazardowych w prawie Unii Europejskiej. Folia Iuridica Wratislaviensis, 3 (2), 139-184.

Binde, P. (2007). Gambling and religion: Histories of concord and conflict. Journal of Gambling Issues, 6 (20), 153-157.

European Gambling \& Betting Association, Market Reality (2016). Pobrane z: http://www. egba.eu/facts-and-figures/market-reality (4.05.2017).

European Gaming \& Betting Association. Sponsoring sportu - firmy bukmacherskie w Polsce i Europie (2015),, pobrane z: http://e-playbet.com/wp-content/uploads/2015/11/Sponsoring-sportu-firmy-bukmacherskie-w-Polsce-i-Europie.pdf, (1.05.2017).

Izryadnova, O. (2016). Analysis of the Global Practice of State Regulation of Activities in the Field of Gambling and Gaming Zone Management Practices. Pobrane z: https://papers.ssrn.com/sol3/papers.cfm?abstract_id=2767341 (2.05.2017).

Pieszin, N., Paszin, A. (2016). K voprosu o razvitii ekonomiki sporta, azartnyh igrahi i prestupnom povedenii. O nekotoryh kriminologicheskih i pravovyh problemah. National Interests: Priorities and Securities, 2016 (2), 152-161.

Roland Berger Group (2016). Regulacje w zakresie rynku zakładów wzajemnych online w Polsce. Warszawa: Roland Berger Group.

Rub90 (2017). Analiticzeskij obzor bukmekerskogo rynka za 2016 god. Pobrane z: https:// rub90.ru/bookie/analytics/analiticheskie-obzory/analiticheskiy-obzor-bukmekerskogo -rynka-za-2016-god/ (5.05.2017).

Surebety (2016). Pobrane z: http://www.surebety.pl/artykul/ustawa-hazardowa-2016 (2.05.2017).

The European Football Jersey Report 2015/2016 (2016). Pobrane z: http://nielsensports.com/ european-football-jersey-report-2015-2016 (6.05.2017).

Thorpe, D. (2016). How the UK gambling industry has impacted the economy. Pobrane z: http:/www.whatinvestment.co.uk/uk-interest-rates-not-going-up-and39anytime-soonand39-and-may-even-fall-from-here-agree-analysts-2515256/ (16.05.2017).

Węgrzecka-Giluń, J. (2012). Przewodnik dla rodziców. Uzależnienia behawioralne: hazard i internet. Warszawa: Fundacja ETOH.

Zasadzki, M., Zasadzki, W. (2010). Wykorzystanie metody analizy kosztów i korzyści funkcjonowania przedsiębiorstw branży hazardowej w badaniu wpływu na lokalną gospodarkę. Studia Zarządzania i Finansów Wyższej Szkoły Bankowej w Poznaniu, 1, 81-94. 


\title{
ANALYSIS OF THE BETTING REGULATIONS IN SELECTED EU COUNTRIES: THE IMPACT ON THE LOCAL ECONOMY
}

\begin{abstract}
With an increasing global technology development, the gambling market is becoming a widely accepted form of entertainment and gaining a significant importance for the economies of different countries. This study discusses the issues related to betting market while providing a comparative analysis of the legal and tax regulations of betting markets in selected countries of the European Union. The analysis indicates that the controlled liberalization model is the dominating approach within the EU Member States. Furthermore, when comparing with the alternative - restrictive model, the controlled liberalization policy enables more dynamic betting market growth while providing several benefits for local economies, e.g. increased budget revenues.
\end{abstract}

Keywords: gambling, betting, offshore operators, Gross Gaming Revenue tax, Polish Gambling Law

JEL codes: K20, K34, Z10, Z20 